\title{
EVALUATION OF THE EFFICIENCY OF REMOVING SANITATION INDICATORS IN THE PROCESS OF BIOLOGICAL WASTEWATER TREATMENT
}

\author{
Iwona Paśmionka ${ }^{\bowtie}$ \\ Department of Microbiology and Biomonitoring, Faculty of Agriculture and Economics, University of Agriculture in Krakow, \\ al. Mickiewicza 24/28, 30-059 Krakow
}

\begin{abstract}
Aim of the study

The aim of the study was to assess the effectiveness of biological wastewater treatment in the process of eliminating sanitation indicators at the Biological Sewage Treatment Plant in Piwniczna Zdrój.

Material and methods

The microbiological analyses included determinations of the following types of bacteria: the coliforms, Escherichia coli, faecal enterococci, Salmonella spp., Shigella spp. and Clostridium perfringens. The standard dilution method was used for determination of indicator bacteria (using from seven to ten dilutions).

Results and conclusions

The degree of contamination of raw sewage with sanitation indicators was comparable during all research series. During biological wastewater treatment, the elimination of the studied indicators was very high and remained at the level of $85-100 \%$. The conducted analyses indicate that the tested sewage treatment plant works at a high level of elimination of microbial contaminants.
\end{abstract}

Keywords: sanitation indicators, biological treatment, activated sludge, raw sewage, purified sewage

\section{INTRODUCTION}

Indicator bacteria used to determine the sanitation condition of water come not only from carriers but from the entire population of humans and warm-blooded animals (Błaszczyk and Krzyśko-Łupicka, 2013; Jóźwiakowski et al., 2009). Their presence indicates fecal pollution, and thus the danger of water contamination with pathogenic microorganisms (Bodzek et al., 2019).

Wastewater, especially municipal wastewater, discharged into rivers and water reservoirs is a potential source of epidemiological threat (Li et al., 2013; Walczak and Donderski, 2007). It brings to the receiver large amounts of microorganisms belonging to the allochtonic flora (Baudisowa, 1997). Most of these microorganisms belong to the natural gastrointestinal flora of humans and higher animals, e.g. Escherichia coli, fecal streptococci, with typical Enterococcus faecalis, or the spore-forming Clostridium perfringens. Wastewater may also contain other pathogenic microorganisms, e.g. dysentery bacteria (Shigella spp.) or typhoid bacteria (Salmonella spp.) (Koivunen et al., 2003; Strzelczyk and Steinhoff-Wrześniewska, 2010; Błaszczyk and Krzyśko-Łupicka, 2013a; Elmund et al. 1999).

Most of the wastewater is treated, but due to the fact that disinfection is not used in classic wastewa-

凶e-mail: iwona.pasmionka@urk.edu.pl 
ter treatment plants, it contributes to surface water contamination (Hai et al., 2014; Bodzek et al., 2019). During purification, the amount of most microorganisms is reduced (Till et al., 1998; Koivunen et al. 2003; George et al., 2002). However, a very high concentration of fecal bacteria, fungi, viruses, protozoa and eggs of intestinal parasites in raw sewage means that they enter the environment in large quantities, contained within the treated sewage (Ottoson et al., 2006). In Europe, the most common etiological factors of water-borne diseases are the bacteria, which cause dysentery: Shigella sonnei, Shigella dysenteriae, Shigella boydii; and typhoid bacteria Salmonella typhi (Walczak and Donderski, 2007). In the gastrointestinal tract of humans and warm-blooded animals, Escherichia coli, fecal streptococci and spore anaerobes of Clostridium perfringens have been found to be persistent (Harb and Hong, 2017). An obligatory indicator in most countries is Escherichia coli. Its presence indicates fresh fecal contamination and the possibility of pathogenic microorganisms in the water (Kazmi et al., 2008).

With the above in mind, the purpose of the research was to assess the effectiveness of biological wastewater treatment in terms of eliminating sanitation indicators. In the analyses we have carried out, the titres of coliforms, Escherichia coli and enterococci, as well as the number of Clostridium perfringens, Salmonella spp. and Shigella spp., were determined in raw and biologically treated sewage.

\section{MATERIAL AND METHODS}

The research was carried out at the Biological Sewage Treatment Plant in Piwniczna Zdrój. It is a mechanical-biological sewage treatment plant located in the southern part of Lesser Poland, on the left bank of Poprad River. The treatment plant scheme is presented in Figure 1. This sewage treatment plant can receive about $2,000 \mathrm{~m}^{3}$ of sewage daily, generated by the inhabitants of the municipality, holiday homes, private quarters, medical spa, as well as mineral water bottling plant and various small service facilities. Wastewater flows into the treatment plant via a collector and then passes through a mechanical sieve combined with a screening press. Then the wastewater flows into the sand catcher with mechanical sand removal. After the sand catcher, wastewater flows by gravity into the pumping station and is pumped to Biocompact reactors, which are used for biological wastewater treatment applying the method of low-load activated sludge. Biological reactors have four zones: anaerobic, hypoxic, aerobic

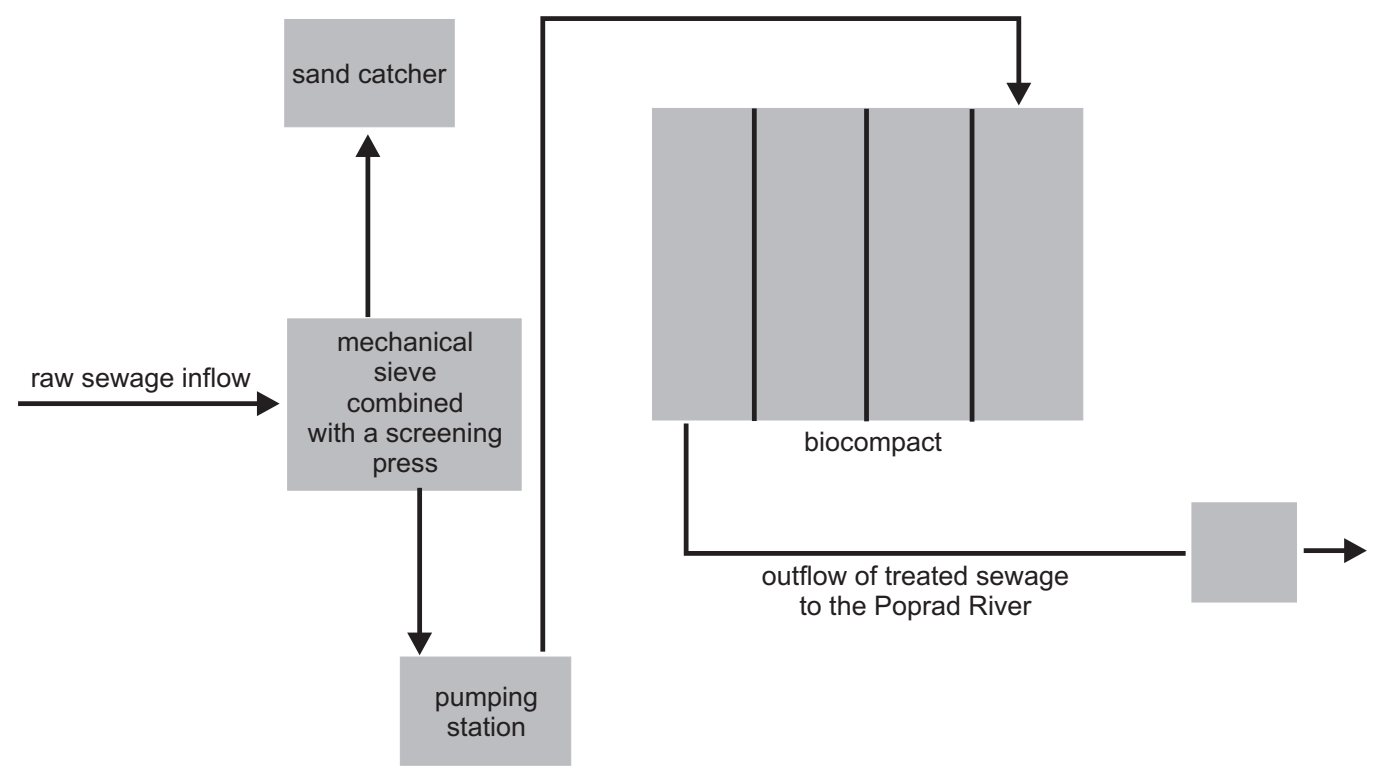

Fig. 1. An overview diagram of the Biological Sewage Treatment Plant in Piwniczna Zdrój

Source: own work. 
(where nitrification occurs) and separation (replacing the classic secondary settler). Treated sewage flows to the receiver, which is the Poprad River.

To carry out the research, two points were designated:

1. raw sewage inlet

2. purified sewage outlet

The analyses were performed in nine replications from October 2018 to June 2019. The microbiological analyses included determinations of the following types of bacteria: coliforms, Escherichia coli, faecal enterococci, Salmonella spp., Shigella spp. and Clostridium perfringens. Wastewater samples were collected according to the instructions for collecting, handling and storage given in PN-EN 25667-2 (1999) and PN-EN ISO 5667-3 (2005). The standard dilution method was used for the determination of indicator bacteria (using between seven and ten dilutions). Coliforms titre was determined with the fermentation method by inoculation of decimal dilutions of samples in a binary system into Ejkman liquid medium (lactose, bromocresol purple) in test tubes with Dürham tubes, followed by incubation at $37^{\circ} \mathrm{C}$ and $44^{\circ} \mathrm{C}$. The results were read after 24 and 48 hours of culturing. Results were accepted as positive when the medium changed colour completely (from purple to yellow) and gas was produced. In order to determine the Escherichia coli titre, a small amount of material was transferred to TBX agar using a sterile loop from tubes in which coliforms were found (PN-C-04615-05 1975, PN-C-04615-07 1977). Cultures were incubated at $44^{\circ} \mathrm{C}$ for 24 hours. TBX agar is a chromogenic medium on which $E$. coli grows in the form of blue-green colonies. Enterococcal titre was determined by tube test in Chromocult medium Enterococci broth containing sodium azide and bromocresol purple. Azide and sulfate (IV) present in the medium inhibit the development of Gram-negative accompanying bacteria, and Gram-positive bacteria are slightly inhibited by low concentrations of crystal violet, whereas streptococci do not respond to the action of this compound at such concentration. Cultures made in this way were incubated at $37^{\circ} \mathrm{C}$ for $24-48 \mathrm{~h}$. Turbidity and discoloration of the medium from purple to yellow was considered positive (PN-C 04615-25 2008). The number of Salmonella spp., Shigella spp. (PN-EN ISO 19250 2013) and Clostridium perfringens (PN-EN 26461-2 2001) were determined using strongly-selective media (Salmonella-Shigella agar and $\mathrm{m}-\mathrm{CP}$ agar, respectively). Cultures were incubated at $37^{\circ} \mathrm{C}$ for 24 hours. Salmonella spp. on SS medium forms transparent colonies with a dark center, while Shigella spp. colonies have a light pink color. Clostridium perfringens on $\mathrm{m}-\mathrm{CP}$ agar grows in the form of black-colored colonies. The number of grown colonies was converted into colony forming units (CFU) in $1 \mathrm{~cm}^{3}$ of tested sewage using the formula:

$$
N=\frac{\sum_{i=1}^{n} x \cdot y}{n}
$$

$\mathrm{N}$ - number of colony forming units (CFU) in 1 $\mathrm{cm}^{3}$ of sewage

$\mathrm{x}$ - number of colonies grown

$\mathrm{y}-$ dilution

$\mathrm{n}-$ number of readings.

\section{RESULTS AND DISCUSSION}

Titres and colony forming units (CFU) of selected sanitation indicators in raw and purified sewage in individual research series are presented in Table 1 and Table 2.

In the raw sewage, in the first series of tests (October 2018), the titre of coliforms and Escherichia coli was $10^{-4}$, whereas the enterococcal titre was $10^{-3}$ (see: Table 1). A smaller amount of enterococci, compared to coliforms and Escherichia coli, was also observed in municipal sewage by Ottoson et al. (2006). After biological treatment, the number of the above sanitation indicators decreased (see: Table 2). Visible reduction in the number of coliforms, Escherichia coli and enterococci, indicates the correct operation of activated sludge in terms of their elimination. Smyłła et al. (2003) report that in classic wastewater treatment plants fecal bacteria are reduced by one to three orders of magnitude, which is confirmed by the data obtained in this study. The number of other sanitation indicators also decreased significantly. Bacteria from the genus Salmonella have been removed in $100 \%$, which indicates a very high efficiency in removing these bacteria. The number of other indicators also decreased to a high degree: Shigella spp. by $99.72 \%$ and Clostrid- 
Paśmionka, I. (2020). Evaluation of the efficiency of removing sanitation indicators in the process of biological wastewater treatment. Acta Sci. Pol., Formatio Circumiectus, 19 (2), 15-22. DOI: http://dx.doi.org/10.15576/ASP.FC/2020.19.2.15

Table 1. Titre and number of sanitation indicators in raw sewage

\begin{tabular}{|c|c|c|c|c|c|c|c|c|c|}
\hline \multirow{2}{*}{ Sanitary indicator } & \multicolumn{9}{|c|}{ No. of analysis } \\
\hline & 1 & 2 & 3 & 4 & 5 & 6 & 7 & 8 & 9 \\
\hline Bacteria of the coli group ${ }^{1)}$ & $10^{-4}$ & $10^{-4}$ & $10^{-5}$ & $10^{-5}$ & $10^{-5}$ & $10^{-5}$ & $10^{-5}$ & $10^{-5}$ & $10^{-4}$ \\
\hline Escherichia coli ${ }^{1)}$ & $10^{-4}$ & $10^{-4}$ & $10^{-4}$ & $10^{-5}$ & $10^{-5}$ & $10^{-5}$ & $10^{-5}$ & $10^{-5}$ & $10^{-4}$ \\
\hline Enterococcus ${ }^{1)}$ & $10^{-3}$ & $10^{-6}$ & $10^{-5}$ & $10^{-5}$ & $10^{-5}$ & $10^{-5}$ & $10^{-5}$ & $10^{-5}$ & $10^{-4}$ \\
\hline Salmonella sp. ${ }^{2)}$ & 50 & 40 & 300 & 40 & 14 & 0 & 140 & 170 & 40 \\
\hline Shigella sp. ${ }^{2)}$ & 65000 & 9400 & 12000 & 12400 & 8750 & 9450 & 8700 & 36000 & 9800 \\
\hline Clostridium perfringens $^{2)}$ & 15400 & 8350 & 12350 & 7460 & 5403 & 8050 & 14000 & 9400 & 6500 \\
\hline
\end{tabular}

${ }^{1)}$ titre of, ${ }^{2)} \mathrm{cfu}$

Table 2. Titre and number of sanitation indicators in purified sewage

\begin{tabular}{|c|c|c|c|c|c|c|c|c|c|}
\hline \multirow{2}{*}{ Sanitary indicator } & \multicolumn{9}{|c|}{ No. of analysis } \\
\hline & 1 & 2 & 3 & 4 & 5 & 6 & 7 & 8 & 9 \\
\hline Bacteria of the coli group ${ }^{1)}$ & $10^{-2}$ & $10^{-2}$ & $10^{-4}$ & $10^{-3}$ & $10^{-3}$ & $10^{-2}$ & $10^{-2}$ & $10^{-3}$ & $10^{-1}$ \\
\hline Escherichia coli ${ }^{1)}$ & $10^{-2}$ & $10^{-2}$ & $10^{-4}$ & $10^{-3}$ & $10^{-3}$ & $10^{-2}$ & $10^{-2}$ & $10^{-3}$ & $10^{-1}$ \\
\hline Enterococcus ${ }^{1)}$ & $10^{-2}$ & $10^{-3}$ & $10^{-4}$ & $10^{-4}$ & $10^{-4}$ & $10^{-2}$ & $10^{-2}$ & $10^{-4}$ & $10^{-2}$ \\
\hline Salmonella sp. ${ }^{2)}$ & 0 & 0 & 28 & 6 & 0 & 0 & 0 & 0 & 0 \\
\hline Shigella sp. ${ }^{2)}$ & 182 & 196 & 1000 & 1305 & 520 & 220 & 93 & 825 & 132 \\
\hline Clostridium perfringens ${ }^{2)}$ & 58 & 125 & 1325 & 703 & 125 & 127 & 17 & 332 & 121 \\
\hline
\end{tabular}

${ }^{1)}$ titre of, ${ }^{2)} \mathrm{cfu}$

ium perfringens by $99.62 \%$ (see: Tables 1 and 2). The obtained results are more satisfying than the literature data as reported by Olańczuk-Neyman et al. (2003) in the "East" sewage treatment plant in Gdańsk, where elimination of Clostridium perfringens in approx. 90\% was observed. According to Koivunen et al. (2003) and Harb and Hong (2017), the degree of reduction in the process of biological wastewater treatment for Salmonella spp. is $55-98 \%$. In the discussed analysis, the amount of Shigella spp. and Clostridium perfringens in the wastewater flowing into the treatment plant was the highest in comparison with the remaining research months. However, due to the high efficiency of biological treatment, a small amount of these went to the receiver, compared to the number that was in the raw sewage.

In the second research series carried out in November 2018, in sewage flowing into the treatment plant, the coliforms and Escherichia coli titre, as in the previous month, was $10^{-4}$. In contrast, enterococcal titres differed significantly from the previous analysis and amounted to $10^{-6}$ (see: Table 1). These results differ from the data contained in the literature (George et al., 2002). Also the amount of Shigella spp. was significantly lower than in the previous month (see: Table 1). After biological treatment, the number of coliforms, Escherichia coli and enterococci was reduced (see: Table 2). The reduction in the number of these bacteria is highly significant and, as in the previous research month, the results obtained were confirmed in the literature (Smyłła et al., 2003). In the conducted tests, as in October, high removal efficiency of Salmonella spp. (100\%), Shigella spp. (97.92\%) and Clostridium perfringens $(98.50 \%)$ was found (see: Table 1 and 2). The efficiency of removing sanitation indicators in this research month, similarly to the previous series, is higher than the data obtained by Olańczuk-Neyman et al. (2001) or Budzińska et al. (2014).

In December 2018, the titre of coliforms and enterococci in raw sewage was $10^{-5}$, while Escherichia 
coli titre was identical to that in October and November (see: Table 1). After the analysis of biologically treated sewage, a smaller reduction of these microorganisms was observed than in previous research months (see: Table 2). The obtained results indicate a slightly lower effectiveness of the reduction of sanitation indicators, which could be caused by low temperatures affecting the rate of bacterial elimination (Elmund et al., 1999). Low temperatures also increase the survival of allochtonic flora in the aquatic environment, thereby affecting the final purification effect (Koivunen et al., 2003). In December, the number of remaining microbiological indicators also decreased less compared to other analyses. The number of Salmonella spp. decreased by $90.67 \%$, Shigella spp. was reduced by $91.67 \%$, while Clostridium perfringens was eliminated in $89.27 \%$ (see: Tables 1 and 2). The degree of reduction of the above microorganisms is within the range provided by Walczak and Donderski (2007) and is similar to the data obtained by Olańczuk-Neyman et al. (2003); however, compared to previous months, these results differ and show a slightly reduced activity of activated sludge, which translated into a worse effect of biological wastewater treatment in terms of the elimination of the studied indicators.

The results of the fourth analysis, carried out in January 2019, were almost identical to those in the previous series of studies. In raw sewage, the titre of coliforms, Escherichia coli and enterococci was $10^{-5}$ (see: Table 1). In the process of biological purification, the number of these microorganisms decreased, the titre of coliforms and Escherichia coli was $10^{-3}$, and faecal streptococci $10^{-4}$ (see: Table 2). The decrease in the number of indicators is comparable to the data provided by Smyła et al. (2003) and indicates good work of activated sludge, however it is not as high as in the first or second research series. The reason for the lower removal efficiency of the examined indicators may be, as in December, persistent low temperatures, which significantly reduced the rate of elimination of the above microorganisms. This is confirmed by the reduction in the number of remaining bacteria, whose numbers have decreased to a similar extent as in the previous research series. The removal efficiency of Salmonella spp. was at the level of $85 \%$ (see: Tables 1 and 2), which indicates a high purification effect. However, compared to previous research months, the effect of removing these bacteria was the lowest. Elimination of Shigella spp. (89.48\%) was at a similar level as the reduction of Salmonella spp. (see: Tables 1 and 2), indicating also the lowest degree of their removal. The effectiveness of biological treatment in the elimination of Clostridium perfringens was $90.58 \%$ (see: Tables 1 and 2). This result is comparable to literature data (Budzińska et al., 2014).

The next, fifth research series was made in February 2019. In raw sewage, the titres of coliforms, Escherichia coli and fecal streptococci were identical to those in January and were at the level of $10^{-5}$ (see: Table 1). Also after biological purification, the effect of elimination these indicators was identical to the previous analysis. The titres of coliforms and Escherichia coli were $10^{-3}$, and enterococci $10^{-4}$ (see: Table 2). The number of other sanitation indicators during biological wastewater treatment decreased slightly more than in the previous research month. The reason for the higher efficiency of elimination of these microorganisms could have been the increase in temperatures, which significantly contributed to the improvement of the quality of activated sludge work, thus improving the final purification effect (Koivunen et al., 2003). The number of Salmonella spp., as in the first and second research series, was reduced by $100 \%$, which proves the very high efficiency of their removal. Shigella spp. was removed in $94.06 \%$, in relation to the amount of bacteria flowing into the treatment plant. The amount of Clostridium perfringens decreased by $97.69 \%$ (see: Table 1 and Table 2). The obtained results indicate a very high activity of activated sludge, which influenced the effectiveness of removing a significant amount of isolated bacteria from sewage. In this analysis, the degree of reduction of bacterial contaminants was higher compared to the results of previous analyses, which indicates an improvement in the efficiency of the treatment plant.

In March 2019, in raw sewage the titres of coliforms, Escherichia coli and fecal streptococci were $10^{-5}$ (see: Table 1). In treated wastewater, the amount of the above-mentioned microbiological indicators decreased, their titre was at the level of $10^{-2}$ (see: Table 2), indicating the best treatment effect from all previous analyses. In the biological treatment process, the number of other sanitation indicators also decreased significantly. The amount of Shigella $\mathrm{psp}$. decreased by 
$97.67 \%$ in relation to the wastewater flowing into the treatment plant, the degree of reduction of Clostridium perfringens was $98.42 \%$, while Salmonella spp. was not detected in the samples of the tested wastewater (see: Table 1 and Table 2). This analysis confirmed the high efficiency of removal of indicator bacteria during biological wastewater treatment. A satisfactory degree of elimination of the above microorganisms, as in the previous research month, indicates very good performance of activated sludge.

The next analysis, performed in April 2019, obtained very similar results compared to the previous month (see: Table 1 and Table 2). Its results show that the sewage treatment plant is working well and, as in the previous month, it is comparable to the extent of fecal bacteria elimination, given by Smyłła et al. (2003) and Budzińska et al. (2011). A large decrease in the number of other indicators was also found in the sample of biologically treated wastewater, confirming the high efficiency of the treatment. Salmonella spp. was removed in $100 \%$, Shigella spp. in $98.93 \%$, and Clostridium perfringens in $99.88 \%$ (see: Tables 1 and Table 2), which demonstrates a high efficiency of biological treatment.

The eighth research series (May 2019) obtained similar results to previous analyses. In raw sewage, the titres of coliforms, Escherichia coli and fecal streptococci were $10^{-5}$ (see: Table 1 ). In treated wastewater, as in the fourth and fifth research series, smaller amounts of these bacteria were found (see: Table 2). These results are slightly worse compared to the previous two analyses, but they still indicate sufficient sewage treatment. The removal of indicator bacteria has also been confirmed by the elimination of Salmonella spp., Shigella spp. and Clostridium perfringens. The achieved degree of reduction of the above bacteria was as high as in the previous three research series and amounted to Salmonella sp. 100\%, Shigella sp. $97.71 \%$, Clostridium perfringens $96.47 \%$ (see: Tables 1 and Table 2).

In June 2019, the last analysis was carried out. In raw sewage, the titres of coliforms, Escherichia coli and fecal streptococci were $10^{-4}$ (see: Table 1). During biological treatment, the number of these indicators decreased. The titres of coliforms and Escherichia coli were $10^{-1}$, and enterococci $10^{-2}$ (see: Table 2 ). The obtained degree of reduction indicates high activity of activated sludge and efficient performance of the treatment plant. In the above research month, there was less Salmonella spp., Shigella spp. and Clostridium perfringens in raw sewage (see: Table 1), which, combined with a high biological treatment effect, resulted in high quality of biologically treated sewage (see: Table 2). Salmonella spp. was eliminated $100 \%$, Shigella spp. in $98.65 \%$, while the amount of Clostridium perfringens was reduced by $98.14 \%$, which, as in previous studies, gives a better purification result than that obtained by Olańczuk-Neyman et al. (2003) in the „East” sewage treatment plant in Gdańsk.

\section{CONCLUSIONS}

1. The degree of contamination of raw sewage with sanitation indicators was comparable during all research series.

2. During biological wastewater treatment, the elimination of the studied indicators was very high and remained at the level of $85-100 \%$.

3. The low temperatures of December 2018 and January 2019 influenced the effectiveness of removing the studied microorganisms. In these months, the average reduction ratio was around $90 \%$.

4. Salmonella spp. and coliform bacteria were most effectively eliminated.

5. The least effective biological treatment was observed for Shigella spp. and enterococci.

6. The Biological Sewage Treatment Plant in Piwniczna Zdrój operates at a high level in the scope of elimination of the tested sanitation indicators.

\section{REFERENCES}

Baudisowa, D. (1997). Evaluation of Escherichia coli as the main indicator of faecal pollution. Wat. Sci. Tech., 35 $(11-12), 333$.

Błaszczyk, K., Krzyśko-Łupicka, T. (2013). Microbial diversity of sewage sludge. Proc ECOpole., 7 (2), 461$-466$.

Błaszczyk, K., Krzyśko-Łupicka, T. (2013a). Microbiological and physico-chemical composition of sewage sludge derived from the food industry. Chem Didact Ecol Metrol., 18 (1-2), 89-95.

Bodzek, M., Konieczny, K., Rajca, M. (2019). Membranes in water and wastewater disinfection - review. Arch. Environ. Prot., 45 (1), 3-18. 
Paśmionka, I. (2020). Evaluation of the efficiency of removing sanitation indicators in the process of biological wastewater treatment. Acta Sci. Pol., Formatio Circumiectus, 19 (2), 15-22. DOI: http://dx.doi.org/10.15576/ASP.FC/2020.19.2.15

Budzińska, K., Jurek, A., Szejniuk, B.,Wroński, G. (2011). Efficiency of bacteriological pollution removal in sewage treatment using biological ponds. Rocz. Ochr. Środ., 13 (1), 1519-1530.

Budzińska, K., Szejniuk, B., Traczykowski, A., Jurek A., Michalska, M., Berleć, K. (2014). Effectiveness of removing microbiological pollutions from wastewater with activated sludge method. Environ. Prot. Eng., 40 (4), 53-68.

Elmund, G.K., Allen, M.J., Rice, E.W. (1999). Comparison of Escherichia coli, Total Coliform and Faecal Coliform Populations as Indicators of Wastewater Treatment Efficiency. Wat. Env. Res., 71(3), 332-339.

George, I., Crop, P., Servais P. (2002). Fecal coliform removal in wastewater treatment plants studied by plate counts and enzymatic methods. Water Res., 36 (10), 2607-2617.

Hai, F.I., Riley, T., Shawkat, S., Magram, S.F., Yamamoto, K. (2014). Removal of pathogens by membrane bioreactors: a review of the mechanisms, influencing factors and reduction in chemical disinfectant dosing. Water, 6 (12), 3603-3630.

Harb, M., Hong, P.Y. (2017). Molecular-based detection of potentially pathogenic bacteria in membrane bioreactor (MBR) systems treating municipal wastewater: a case study. Env. Sci. Pollut. Res., 24 (6), 5370-5380.

Jóźwiakowski, K., Korniłłowicz-Kowalska, T., Iglik, H. (2009). Estimation of sanitary status of sewage treated in constructed wetland systems. Contemporary Problems of Management and Environmental Protection. Sewages and Waste Materials in Enviromnent, 4, 7-21.

Kazmi, A.A., Tyagi, V.K., Trivedi, R.C., Kumar, A.A. (2008). Coliforms removal in full-scale activated sludge plants in India. J. Environ. Manage., 87 (3), 415-419.

Koivunen, J., Siitonen, A., Heinonen-Tanski, H. (2003). Elimination of enteric bacteria in biological-chemical wastewater treatment and tertiary filtration units. Water Res., 37 (3), 690-698.

Li, D., Zeng, S., Gu, A.Z., He, M., Shi, H. (2013). Inactivation, reactivation and regrowth of indigenous bacteria in reclaimed water after chlorine disinfection of a municipal wastewater treatment plant. J. Environ. Sci., 25 (7), 1319-1325.

Olańczuk-Neyman, K., Stosik-Fleszar, H., Mikołajski, S. (2001). Elimination of indicator bacteria removal in wastewater treatment processes. Pol. J. Environ. Stud., 10 (6), 457-461.
Olańczuk-Neyman, K., Geneja, M., Quant, B., Dembińska, M., Kruczalak, K., Kulbat, E., Kulik-Kuziemska, I., Mikołajski, S., Gielert, M. (2003). Microbiological and Biological Aspects of the Wastewater Treatment Plant „Wschód” in Gdańsk. Pol. J. Environ. Stud., 12(6), 747-757.

Ottoson, J., Hansen, A., Bjorlenius, B., Norder, H., Stenstrom, T.A. (2006). Removal of viruses, parasitic protozoa and microbial indicators in conventional and membrane processes in a wastewater pilot plant. Water Res., 40(7), 1449-1457.

PN-C-04615-05. (1975). Woda i ścieki. Badania mikrobiologiczne. Oznaczanie bakterii grupy coli metoda fermentacyjną probówkową.

PN-C-04615-07. (1977). Woda i ścieki. Badania mikrobiologiczne. Oznaczanie bakterii grupy coli typu kałowego (fekalnego) metodą fermentacyjną probówkową.

PN-EN 25667-2. (1999). Jakość wody. Pobieranie próbek. Wytyczne dotyczące technik pobierania próbek.

PN-EN 26461-2. (2001). Jakość wody. Wykrywanie i oznaczanie ilościowe przetrwalników beztlenowców redukujących siarczyny (clostridia). Część 2: Metoda filtracji membranowej.

PN-EN ISO 5667-3. (2005). Jakość wody. Pobieranie próbek. Część 3: Wytyczne dotyczące utrwalania i postępowania z próbkami wody.

PN-C-04615-25. (2008). Woda i ścieki. Badania mikrobiologiczne. Część 25: Oznaczanie enterokoków kałowych metodą probówkową.

PN-EN ISO 19250-07. (2013). Jakość wody. Wykrywanie Salmonella spp.

Smyłła, A., Piotrowska-Seget, Z., Tyflewska, A. 2003. Pathogenic bacteria hazard in surface waters. AUMC, Limnological Papers, 110 (13), 159-169.

Strzelczyk, M., Steinhoff-Wrześniewska, A. (2010). Indicators of water absorbability and quantity of wastewater formed in selected branches of food industry. Pol. J. Chem. Technol., 12 (4), 6-10.

Till, S. W., Judd, S.J., Mclonghlin, B. (1998). Reduction of faecal coliform bacteria in sewage effluents using a microporous polymeric membrane. Wat. Res., 32 (5), 1417-1422.

Walczak, M., Donderski, W. (2007). Elimination of indicators (TC, FC, FS) and Enterobacteriaceae family bacteria during the sewage treatment process. Pol. J. Natur. Sci., 22 (2), 294-305. 


\section{OCENA SKUTECZNOŚCI USUWANIA WSKAŹNIKÓW SANITARNYCH W PROCESIE BIOLOGICZNEGO OCZYSZCZANIA ŚCIEKÓW}

\section{ABSTRAKT}

\section{Cel pracy}

Celem badań podjętych w niniejszej pracy była ocena efektywności biologicznego oczyszczania ścieków w zakresie eliminacji wskaźników sanitarnych w Biologicznej Oczyszczalni Ścieków w Piwnicznej Zdroju.

\section{Materiat i metody}

W przeprowadzonych analizach oznaczano bakterie grupy coli, Escherichia coli, enterokoki kałowe, Salmonella spp., Shigella spp. i Clostridium perfringens. Do oznaczenia bakterii wskaźnikowych zastosowano standardową metodę rozcieńczenia w zakresie od siedmiu do dziesięciu.

\section{Wyniki i wnioski}

Stopień zanieczyszczenia ścieków surowych wskaźnikami sanitarnymi był porównywalny we wszystkich seriach badawczych. Podczas biologicznego oczyszczania ścieków eliminacja badanych wskaźników była bardzo wysoka i utrzymywała się na poziomie $85-100 \%$. Przeprowadzone analizy wskazują, że badana oczyszczalnia ścieków działa na wysokim poziomie eliminacji zanieczyszczeń mikrobiologicznych.

Słowa kluczowe: ścieki surowe, osad czynny, wskaźniki sanitarne, oczyszczanie biologiczne, ścieki oczyszczone 